\title{
REVISITING THE NOTION OF INNOVATION AND ITS IMPACT ON THAILAND'S ECONOMIC POLICY: A CASE STUDY OF JAPANESE MANGA
}

\author{
Jiraporn Phornprapha* \& Weerayuth Podsatiangool \\ *First author \\ The Department of English and Linguistics \\ The Faculty of Liberal Arts \\ Thammasat University \\ (jiraporn.p@arts.tu.ac.th, weerayuth.p@arts.tu.ac.th) \\ DOI: https://doi.org/10.22452/jati.vol24no1.5
}

\begin{abstract}
Innovation has become an important concept that guides policy in almost every organization in Thailand since the government launched the new economic model 'Thailand 4.0' emphasising innovative technology-based manufacturing and services. Nevertheless, this policy seems to emphasise only technological innovation and disregards other aspects of 'innovation'. In this paper, the authors revisit the notion of innovation and apply it to examine Japanese manga which is a major part of the Japanese publishing industry. Over recent decades, Japanese manga has found great success in Southeast Asia. The paper argues that the success of manga may be because it is not just an invention, but it is also an innovation even though it is not directly associated with technology. Applying documentary research focusing on the notion of innovation and Kaya's Schumpeterian trilogy as a framework, the researchers found that the development of manga falls within Schumpeter's five types of innovation. In keeping with the unique characteristics of manga, it is possible to consider it as a non-technological innovation, and a cross-cultural innovation. The study provides new insights into how the concept of 'innovation' can be fully implemented to communicate and project Thai cultural understandings whilst contributing to the development of Thailand's economy, culture, and society.
\end{abstract}

Keywords: innovation, popular culture, manga, Japan, Thailand, cross-cultural innovation 


\section{Introduction}

The term 'innovation' has captivated public attention in Thailand especially in recent years in response to 'Thailand $4.0^{\prime}$ policy, the new economic model that highlights the concept of 'innovation'. The concept is not new in Thailand but has been around for decades. In higher education, innovation has influenced curriculum designs such as 'Technopreneurship and Innovation Management Program' at Chulalongkorn University, 'College of Innovation', 'Digital Transformation \& Innovation Program' at Thammasat University, 'Business Administration Program in Business Innovation Management Program' at Silpakorn University, and 'the Faculty of Innovative Agricultural Management' at Panyapiwat Institute of Management. Now as almost every organization has adopted the Thailand 4.0 policy, the term is increasingly ubiquitous as is evident in the business sector and media such as HR Innovation, Innovative Business Strategies, Innovative Management, among others. However, it is questionable if the concept of innovation is clearly understood since most of the time it tends to refer to only technological innovation whereas other dimensions of the concept are sorely disregarded.

This paper aims to provide insight into comprehensive dimension of innovation in Thailand. According to Iwabuchi (2002), Natsume (2004), and Yamato (2012), Japan has played an important role in various aspects in Southeast Asia, Thailand included. It is regarded as one of the leading countries in Asia in both technological and non-technological innovation. Manga is the epitome of the non-technological innovation that has found great success in many countries around the world (Brienza, 2009; Chan, 2018; Goldstein \& Phelan, 2009; Poitras, 2008). In Thailand, the accomplishment of manga is manifested in the establishment of publishing houses that are solely dedicated to Japanese manga and in its popularity among Thai children who have grown up with Japanese animation broadcast on Thai television for at least thirty years (Podsatiangool, 2017). The paper proposes that innovation does not necessarily refer to technological innovation. By investigating Japanese manga, we are reconceptualizing this 'non-sense' book as 'Cross-Cultural Innovation.' In particular, it is worth clarifying that Japanese manga is not a cultural innovation created only by the Japanese, but a hybridized cultural innovation created from concepts drawn upon unique eastern and western cultures. Ultimately, manga has become a cross cultural communication tool that connects people around the world. The remainder of this paper is divided into the following sections: overview of the issue, background to manga, Japanese manga in Thai society, theoretical framework, research questions, methodology, the case study of manga as a cultural innovation, discussion, and conclusion. 


\section{Overview of the Issue}

Amidst the competition in the global market, new economic models are created to respond to the change in $21^{\text {st }}$ century. 'A Nation of Makers', 'Design of Innovation', 'Made in China 2025', 'Made in India' and 'Creative Economy' among others are new strategic models to compete in the global market. In Southeast Asia, countries have attempted to remain economically competitive with the establishment of ASEAN Economic Community in 2015. Nevertheless, it is necessary for Thailand to take a further step to prepare itself for the competition and to escape from the middle income trap. In 2016, the government launched the new economic model called 'Thailand 4.0 ' or the innovation-based economic model. This model is believed to create so called 'New Engines of Growth' by improving the country's existing five industry groups, (1) food, agriculture and biotech, (2) health, wellness, and bio-med, (3) smart devices, robotics and mechatronics, (4) digital, IoT, AI, and embedded technology, and (5) creative, culture and high value services (Thai Rath, 2016). In practice, however, the policy is widely understood to emphasise technological innovation while other aspects of the 'innovation' concept are disregarded (Banchanon, 2017).

To provide insight into the concept of 'innovation', Japanese manga is used as a case study to demonstrate how the concept was fully implemented to create a non-technological product and brought about Japan's success in a global market.

\section{Background to Manga: Origins and Acceptance in International Trade Book Marketplace}

Manga is widely known as Japanese comics, but it should not be simply defined as such due to its long history and complex cultural background. Manga, written with two Chinese characters [漫画], is translated as irresponsible pictures or various or whimsical pictures. The history of the word can be traced back to when it was first coined by woodblock print master Hokusai Katsushika (A. D. 1760-1849) to denote his humorous, illustrated narratives of Ukiyo-e (literally 'the floating world'). It went through important modifications during the World War II when Japanese society was strongly influenced by the U.S. cultures in many aspects. During that period, popular American comics such as Popeye, Mickey Mouse, and Superman were translated into Japanese and introduced to Japan for the first time. Consequently, Japanese manga artists adopted western concepts and drawing styles in the creation of manga after the exposure to American popular culture after the World War II. That western ideologies have merged into Japanese manga could lead to the misperception about the success of manga in the U.S. market. Manga was not well-received by U.S. readers until recently. On 
the other hand, manga is a huge business in Japan, a main medium of entertainment that is consumed by every demographic in all segments of Japanese society. It is also exported to many Asian and European countries. For this purpose, there are many genres of manga: fantasy, historical, horror and supernatural, humor, politics, religious and spiritual, sci-fi, etc. However, most of the time, it is difficult to identify a genre of manga since one manga may be a combination of more than one genre (Bouissou, 2010; Brienza, 2009; 2014; Bryce \& Davis, 2010; Chen, 2011, 2012; Couch, 2010; Drummond-Mathews, 2010; Goldstein \& Phelan, 2009; Ito, 2005; Johnson-Woods, 2010; Natsume, 2004; Podsatiangool, 2017; Poitras, 2008; Prough, 2010a, 2010b). However, manga should not be confused with anime, another significant entertainment media.

Manga in the international market is closely related to anime, commonly known as Japanese animation. In Japan's domestic market, manga books, printed only in black and white, always have short lives. Among those, only a few of them make their ways to become anime. Chambers (2012) explained that "Manga was the foundation upon which anime was built" (p. 95). Surprisingly, as Chen (2011) pointed out overseas fans usually encounter anime first and manga later on which is the reverse pattern of the Japanese market. In the U.S., for instance, the popularity of anime gave rise to the entry of manga in the trade book market (Prough, 2010a). Similarly, Brienza (2009) found that most fans of Sailor Moon, the famous Japanese manga in the U.S., became interested in manga and anime through their exposure to Sailor Moon on television. This finding is particularly interesting since it indicates that in contrast to Japanese readers, only certain genres of manga are well-received by the U.S. readers. The studies found that the popularity of manga in the U.S. is limited to young adult readers; thus, the genres that well-received are Shōnen Manga and Shōjo Manga (Brienza, 2009; Chen, 2011, 2012; Drummond-Mathews, 2010; Goldstein \& Phelan, 2009; Imaoka, 2010; Natsume, 2004; and Prough, 2010a, 2010b). Shōnen Manga means manga for young adolescent boys or young men whereas Shōjo Manga means manga for young adolescent girls or young women (Brienza, 2009; Bryce \& Davis, 2010; Ito, 2005; Piatti-Farnell, 2013).

Despite the popularity of Manga in the U.S. market, Brienza (2009) suggested that there are two problems in publishing Japanese manga in the U.S. The first is that manga is supposed to be published in weekly or bimonthly magazines and is consumed at a faster pace in Japan than in the U.S. The second is that it is problematic to publish the Japanese right-to-left reading style into the Western left-to-right reading pattern. These factors show why it is difficult to publish manga in time and why overseas fans usually encounter anime first. 


\section{Japanese Manga in Thai Society}

Japanese manga is well-received in Asia from East Asian to Southeast Asian countries. In some countries like Malaysia, although it may be in the initial phase, Japanese manga has demonstrated that it can integrate itself into local culture. manga is not only widely consumed in the country but also inspires Malaysian artists to create their own manga based on Malaysian local identity constructs (Chan, 2018). On the other hand, in Thailand, the consumption of Japanese manga is slightly different. Manga has been popular, especially among young Thai consumers, for more than three decades; some read Japanese manga while some watch them on national TV. The manga market in Thailand is identified as the 'dual structure'. The former structure is Japanese manga while the latter is the local Thai manga that is strongly influenced by Japanese manga (Natsume, 2004). For instance, the Thai manga 'Apaimanee Saga' or 'Meed Tee Sib Sam' are good examples of Japanese-influenced Thai manga in terms of plot, characterisation, and drawing styles.
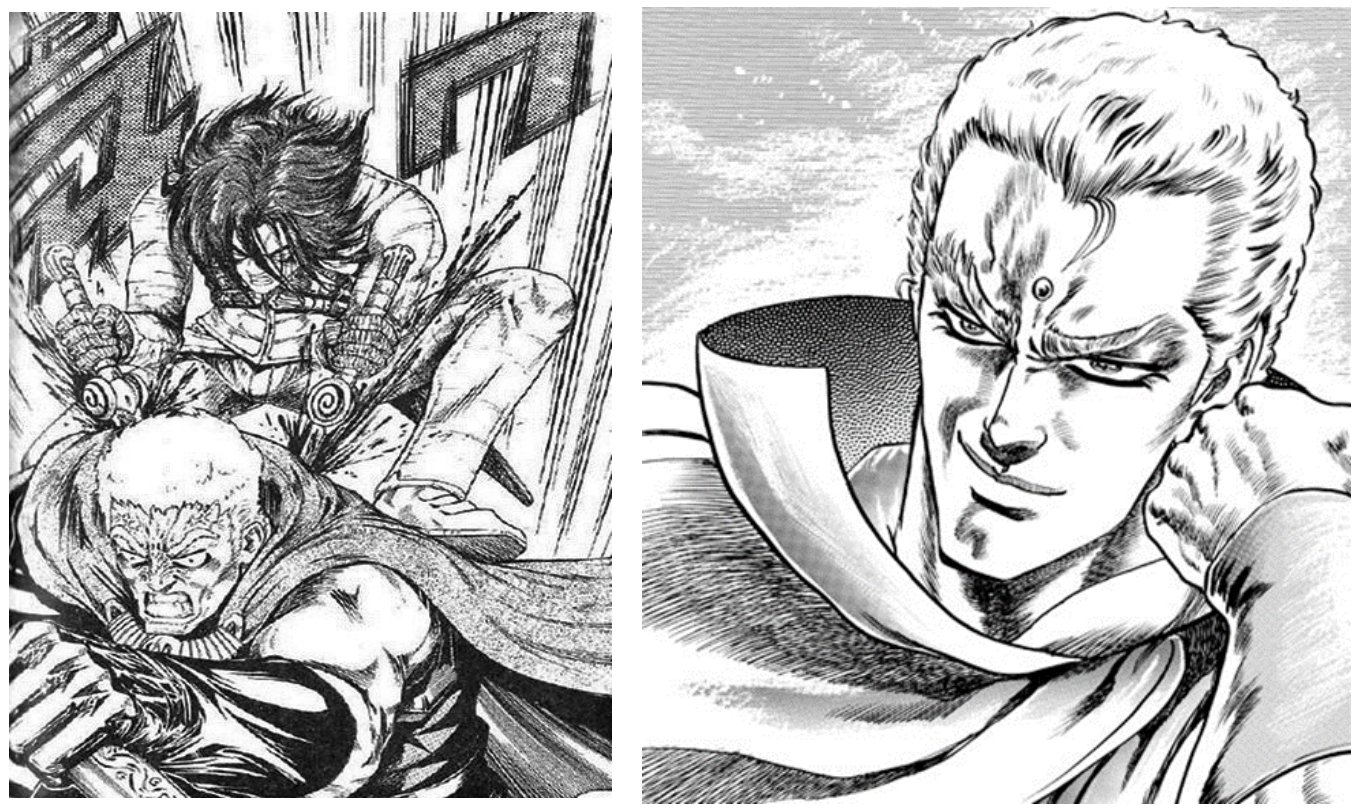

Figure 1: Comparison of drawing style between Meed Tee Sib Sam (left) and Fist of the North Star (right)

(Sources: Vitoonthong \& Champrasert [1994-present]; Okamura \& Hara [19831988].) 

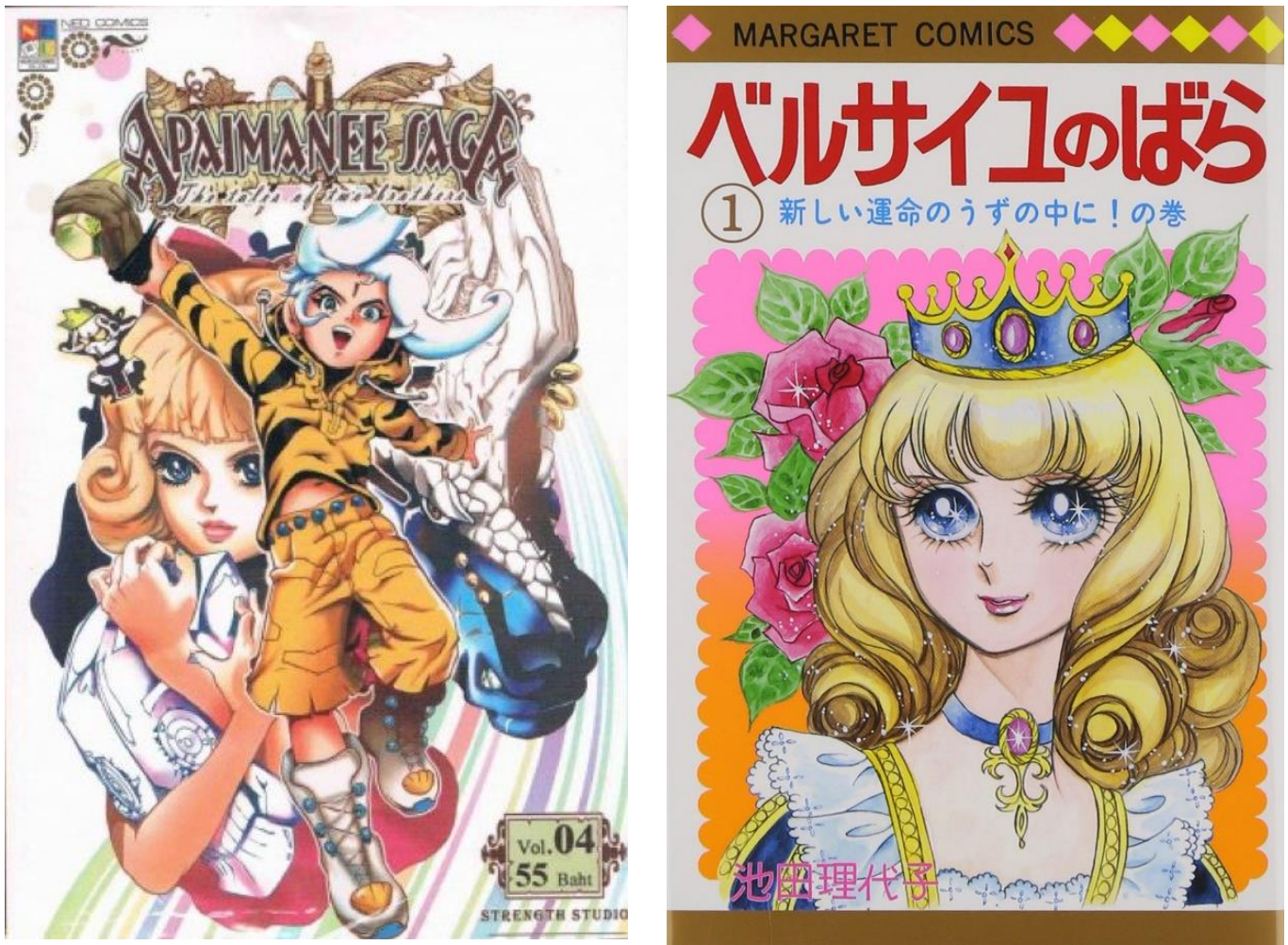

Figure 2: Comparison of book covers between Apaimanee Saga (left) and the Rose of Versailles (right)

(Sources: Anawatkochakorn [1994-1996]; Ikeda [1972-1973].)

The above figures demonstrate the influence of Japanese manga on Thai manga. Figure 1 compares the drawing style of Thai manga, Meed Tee Sib Sam (Vitoonthong \& Champrasert, 1994-present), on the left and Japanese manga, Fist of the North Star (Okamura \& Hara, 1983-1988), on the right. The shape of the face, hairstyle, and outfit of both characters are almost identical. Figure 2 compares the book covers of Thai manga, Apaimanee Saga (Anawatkochakorn, 1994-1996), on the left and Japanese manga, the Rose of Versailles (Ikeda, 19721973), on the right. According to Brophy (2010), Cohn (2010), Chen (2012), and Prough (2010b), the unique Japanese drawing styles for manga are the use of non-Asian hair colors and the big-eye style. The Thai cover appears to apply the same techniques as the Japanese cover.

For the purpose of discussion in this paper, manga is defined as all Japanese style graphic novels printed in black and white by any publishing companies whether as periodicals or books. However, it is not necessary that 
manga artists must be Japanese, or the language of manga should be Japanese. In terms of the plot, it can be fiction or non-fiction.

\section{Theoretical Framework}

The term 'innovation' is ambiguous as there is no consensus about its definition. In Thailand, the concept of innovation in a general sense or even in the media tends to highlight only technological innovation whereas other aspects are less featured.

In fact, the concept of the term goes beyond technology. Therefore, the definition should extend to new technologies as well as new ways of doing things. Porter (1990) suggested that innovation is the key to help the companies achieve competitive advantage. Innovation in the business may then include a new product design, a new production process, or a new marketing approach. However, Porter (1990) seemed to focus on the new application of the ideas as he further defined the term, "It often involves ideas that are not even 'new'-ideas that have been around, but never vigorously pursued" (p. 75). Although Porter made it explicitly that the focus of innovation should not refer to only new things, the researcher did not make distinctions between two commonly interchangeable terms, innovation and invention.

Freeman (1982) and Neely, Filippini, Forza, Vinelli, and Hii (2001) indicated the need to distinguish these two terms. According to Freeman, an invention is a new idea, but an innovation "is accomplished only with the first commercial transaction involving the new product, process, system, or device" (as cited in Neely et al., 2001, p. 114). However, the definition of innovation proposed by Neely et al. (2001) is similar to Porter with the emphasis on the application of the ideas. They further specified that the exploitation of new ideas should be for commercial purposes. In their view, "innovation involves the commercial exploitation of new ideas" (Neely et al., p. 114).

Kaya (2015) also suggested the importance of commercial transaction in an innovation process. Based on Schumpeterain trilogy, Kaya (2015) argued that an innovation process must include the development of new ideas into marketable products and processes. The technological change process should include three stages: invention, innovation, and diffusion (pp. 31-32). Even though 'marketable products' is included in the work by Kaya (2015), the marketing process itself does not receive enough attention.

The marketing process is included in the work by Popa, Preda, and Boldea (2010) which provides an extensive definition of innovation. Like Porter (1990), their study pinpointed the significance of the correlation between innovation and competition, "Intense global competition and technological 
development have made innovation be a source of competitive advantage." (Popa et al., 2010, p. 151). Reviewing many definitions of innovation thoroughly from 1930 to 2001, they provided the summary of the term in which they included technological innovation, organizational innovation, and probably the most interesting one, marketing as innovation.

Building on others' work on the definition of innovation, Wutthirong (2014) defined innovation as "new things that have never existed in any corporation, organization, country, or the world, which must be practical to the contribution of economy, society, or mentality" (original Thai "นวัตกรรม คือ สิ่งใหม่ที่ไม่เคยมีมาก่อนในหน่วยงาน องค์การ ประเทศหรือในโลก และต้องสามารถนำมาใช้ได้จริง เพื่อสร้างให้เกิดประโซชน์ในเชิงเศรษฐูกิจ สังคม หรือจิตใจ"., p. 12).

For the purpose of the discussion on Japanese manga as Cultural Innovation in this paper, the most comprehensive framework of innovation is necessary. As the basis of the discussion, the five types of innovation developed by Joseph A. Schumpeter (as cited in McCraw, 2007) are used. The types of innovation included (McCraw, 2007, p. 73):

(1) The introduction of a new good-that is one with which consumers are not yet familiar-or of a new quality of a good.

(2) The introduction of a new method of production, that is one not yet tested by experience in the branch of manufacture concerned.

(3) The opening of a new market, that is a market into which the particular branch of manufacture of the country in question has not previously entered, whether or not this market has existed before.

(4) The conquest of a new source of supply of raw materials or halfmanufactured goods, again irrespective of whether this source already exists or whether it has first to be created.

(5) The carrying out of the new organization of any industry, like the creation of a monopoly position (for example through trustification) or the breaking up of a monopoly position.

\section{Research Questions}

The study addresses two questions regarding innovation and the government's economic policy in Thailand:

1. Is the concept of innovation limited to technological innovation?

2. Should the Thai government consider a new possibility to implement its Thailand 4.0 policy that highlights the concept of innovation? 
To answer the above questions, the success of Japanese manga is used as a case study. This paper argues that Japanese manga can be successful in a global market even if it is a non-technological innovation. To be even more specific, it is a cultural innovation since its description falls under at least one out of the five types of innovation. As a Japanese cultural innovation, manga has been a key to help Japan to achieve competitive advantage in the cultural market. As Baumol (2015), Kaya (2015), Popa et al. (2010), and Porter (1990) pointed out, innovation is a source of competitive advantage. The researchers believe that Japanese manga has already crossed the line from being invention to into commercial transaction or marketable products. Furthermore, if we discuss it based on Kaya (2015)'s Schumpeterian trilogy, it is already in the stage of diffusion, in which the new products spread across the potential market.

\section{Methodology}

This research applies documentary research focusing on conceptual discussion of the notion of innovation. In addition, the researchers use Kaya's Schumpeterian trilogy as a framework to identify if manga is a non-technological innovation. The following section analyses of Japanese manga using the framework.

\section{The Case Study of Manga as a Cultural Innovation}

Probably before making a claim that manga is a cultural innovation of the Eastern and Western world, it is necessary to justify where Manga is as an invention. Naturally, manga is an invention of Japan by Japanese for Japanese. According to Chen (2011, 2012), Johnson-Woods (2010), Prough (2010a, 2010b), and Roland (2006), the manga artists do not really consider international markets as they focus mainly on Japanese consumers. Manga is one communicative means to convey ideologies, identities, and cultures to its readers. The popularity of manga within many Asian countries and the fact that children and young adults who have never been to Japan become familiar with the country because of Japanese manga and anime proves that manga is a means of cross cultural communication. It is crucial to note once more that Japanese society has been strongly influenced by American culture since the World War II, and manga is no exception (Bouissou, 2010; Brienza, 2009; 2014; Bryce \& Davis, 2010; Chen, 2011, 2012; Couch, 2010; Drummond-Mathews, 2010; Goldstein \& Phelan, 2009; Ito, 2005; Johnson-Woods, 2010; Natsume, 2004; Podsatiangool, 2017; Poitras, 2008; Prough, 2010a, 2010b). Because of the influence of the U.S. culture in manga and the role of the U.S. in disseminating popular cultures around the globe, manga is relatable to many readers across cultures both the East and West. 
However, manga was not successful right away after its attempt to enter the U.S. market.

It is not probably until manga went beyond an invention and became an innovation that manga found its success in the U.S. According to Martin and Nakayama (2010), although the U.S. is the most influential producer of popular culture, its people are rarely exposed to popular culture from outside the country. This is probably why manga has been popular in many countries for decades, but has just become successful in U.S. cultural market. Even as a newcomer in the market, Japanese manga has been so successful that it was recognized by journalist Roland Kelts in the subtitle to his 2006 book, "Japanese Popular Culture Has Invaded the U.S." (Roland, 2006). The sales growth of manga in the U.S. is the best indicator of Japanese manga's accomplishments. In the early $21^{\text {st }}$ century, the U.S. book market witnessed the most significant sales of Japanese comics (Brienza, 2009; Goldstein \& Phelan, 2009; Poitras, 2008). Brienza (2009) provides the following specific data on the sales of manga in the U.S., "Sales grew remarkable 350\% from $\$ 60$ million in 2002 to $\$ 210$ million in 2007" (p. 101). Nowadays, several publishers in the U.S. are established to solely publish Japanese manga such as VIZ Media, Kodansha USA, Tokyopop, and Dark Horse.

The following sections argue that the success of manga in the U.S. market relies on the fact that manga is not simply a Japanese invention but a cultural innovation based on the Schumpeter's five types of innovation (McCraw, 2007).

\section{The introduction of a new good}

In Japan, manga passed the stages of invention, innovation, diffusion a long time ago, even before World War II. Then, as it passed to other Asian countries, Japanese manga went through similar stages as Chen (2011, 2012), Iwabuchi (2002), Natsume (2004), and Yamato (2012) indicated that young people in Asian countries have had a very positive attitude towards and have been exposed to Japanese popular culture for a long time. Moreover, that Asian countries have shared tremendous cultural background with Japan support the achievement of manga in these countries.

Therefore, it is in the U.S. that manga has just started to move from an invention to an innovation. As opposed to Asian market, Japanese manga is a new good to be introduced in the U.S. Brienza (2009) argued that the comic industry in the U.S. focuses on white, adult male consumers and seems to exclude women and children consumers since most plots are about superheroes. Manga publishers in the U.S. had to find a new path to win in the U.S. market. Introducing other genres of manga into the market as new products, they 
succeeded in attracting many readers, especially children, females, and young adults, the groups that were not the original consumers.

These various genres of manga in the U.S. market do not have to be about Japan or Japanese culture. The most popular manga in the U.S. such as Dragon Ball, Sailor Moon, Fullmetal Alchemist, and Saint Seiya are universal and exotic (Chen, 2011), hybridized (Brienza, 2009, 2014), and culturally odorless (Yamato, 2012). In the debate on why readers have a positive response to manga, Brienza (2014) suggested that it is because of its coolness which refers to its notthe-United-States-ness, not its Japaneseness. On the other hand, Yamato (2012) pointed out that the term culturally odorless might be the key for the wide acceptance of Japanese popular culture outside Japan. All in all, these key terms, universal, exotic, hybridized, culturally odorless, and not-the-United-States-ness, are all new concepts for American readers. In other words, manga is a new product in the publishing industry that does not belong to either the East or the West. Thus, it is possible to consider Japanese manga as Cultural Innovation of the East and the West.

\section{The introduction of a new method of production}

Since manga has existed in Japan for centuries, it has been through a number of revolutions in terms of its techniques and concepts. Strongly influenced by American popular culture since World War II in many aspects, modern Japanese manga has western concepts deeply embedded within it. Osamu Tezuka, the father of modern manga (Brophy, 2010; Cohn, 2010; Chen, 2012; Ito, 2005; and Prough, 2010b), developed new techniques and concepts of Japanese manga such as non-Asian hair colors (non-Asian means 'cool'), big-eye style (so that the characters can express more feelings), and representing the characters in manga in high-theatrical modes inherited from Kabuki-style gesticulation and minimalism of Noh.

Because of the two major problems in publishing Japanese manga in the U.S. discussed at the beginning of the paper, there was a need for a new method of production. The first problem is that manga is normally published either weekly or bimonthly and is consumed at a faster pace in Japan than in the U.S. The second problem is that there is a difference in the publishing style between the Japanese right-to-left style and the Western left-to-right style. These two factors explain why it is a challenge to publish manga at the same pace as in Japan and why overseas fans usually encounter anime before manga. Therefore, the distributors of manga and anime implemented at least two new methods of production of the products. First, according to Brienza (2009, 2014), Chen (2011, 2012), and Prough (2010a), as overseas fans usually encounter anime before manga, the distributors had to dub those contents into English, or provide 
English subtitle for their fans to attract them to read the manga which will be published afterwards. Second, those distributors also had to publish the manga at the similar pace as publishers in Japan. Some of the distributors finally came up with ' $100 \%$ Authentic Manga' campaign-with less reediting, insisting on Japanese style right-to-left reading, leaving sound effects untranslated etc. which could help them speed up their manga release schedules successfully. The coming of manga and anime into American publishing market has contributed to a new method of production, or at least a new way of thinking about production in the U.S. publishing industry.

\section{The opening of a new market}

According to Chen (2011, 2012), Iwabuchi (2002), Natsume (2004), and Yamato (2012), people in Asian countries who have experienced Japanese popular culture for decades had a very positive attitude since they shared the similar cultural background. At some point, other Asian countries no longer feel that the Japanese popular culture is something new and exciting. Iwabuchi (2002) pointed out, "the presence of Japanese popular culture in many parts of East/Southeast Asia no longer seems to be something spectacular or anomalous but rather has become mundane in the globalizing (urban) landscape." (pp. 1-2). Even so, the fact remains that Japanese popular culture has won the hearts of consumers in many Asian countries, leading Iwabuchi (2002) to make the conclusion that "Japan is beloved in Asia!" (pp. 1-2). Similar to Iwabuchi (2002), Natsume (2004) found that Japan has a special position in other Asian countries, "(in East Asian countries) Japan is idolized as a leading developed nation (reminiscent of Japanese sentiment following WWII in which American culture was idolized)" (p. 96)." Therefore, manga is no longer a new market for Asian publishing industry. However, it is a different story for the U.S. market. Manga is indeed "the opening of a new market".

Prior to the invasion of manga to the U.S. market, "superheroes "comics were prominent in the publishing industry. To attract American readers, the Japanese manga publishing houses created a new market for their own products with young adults as their main customers. They selected only some genres of manga that matched American readers' preferences, the themes of 'the fantasy and otherworldly' that are commonly found in young adult readers'. This decision marked a new marketing strategy for Japanese manga. In Japan, manga is a product for everyone. Natsume (2004), Poitras (2008), Brienza (2009), Prough (2010), and Podsatiangool (2017) agreed that manga is consumed by all segments of Japanese society, with every demographic and genre represented. On the other hand, in the U.S. and in other western countries, the sales of manga are strategized for young adults. As a result, the success of manga in the U.S. is 
attributed to the marketing strategies of the manga publishing houses in the U.S. (Brienza, 2009, 2014; Chen, 2011, 2012)

\section{The conquest of a new source of supply of raw materials}

Like other products, raw materials are necessary in the production of manga. In other products, raw materials may refer to "Natural or processed resources which are used as an input to a production operation for subsequent transformation into semi-finished and finished goods" (Deloitte Sustainability, British Geological Survey, Bureau de Recherches Géologiques et Minières, Netherlands Organisation for Applied Scientific Research, 2017, p. 8). However, raw materials for manga could refer to ideas, experiences, or opinions and feelings of the Japanese artists. Since World War II, due to the great influence of American popular culture, western concepts have become a new source of supply of raw materials for the plots in manga. Because of the variety of western concepts such as Christianity, Greek and Norse Mythology, Disney, Hollywood etc. embedded in Japanese manga, the manga possess universal, exotic, hybridized, and culturally odorless qualities. In other word, it is not about Japan or Japanese culture anymore.

On the contrary, since manga has established itself in the U.S. market, there are many American cultural artifacts that contain Japanese concepts. For example, Hollywood films, to some extent, applied concepts from Japanese manga such as the Matrix (influenced by the manga Ghost in the Shell), Inception (by the animation Paprika), the Lion King (by the manga Kimba: the White Lion), and Big Hero 6 (highlighted by the Japanese style of cuteness of the characters). Therefore, Japanese manga has also become a new source of supply of raw materials for American animations.

\section{The carrying out of the new organization of any industry}

There are two new organizations that are derived from the coming of manga into the U.S. First, as manga entered the U.S., a new form of business was born from the M\&A (Mergers and Acquisitions) of publishers". Several publishers have been established in the U.S. to solely publish Japanese manga such as VIZ Media, Kodansha USA, Tokyopop, and Dark Horse. Second, what Brienza (2014) called the 'Direct-to-digital publishing collectives' model of business was also established. While it is true that this model of business is not new for the Japanese, as mobile phone networks have distributed manga in the digital space on their networks in mid-2000s, in the U.S., it was not until 2011 that the 'Directto-digital publishing collectives' model began. The bankruptcy of the Border Group in 2011 marked a significant change in the American manga industry; a lot of manga publishers lost the retail stores for their books. However, because 
the readers in the U.S. consumed the manga regardless of brands of publishers, this incident gave an opportunity for other companies to sell manga from all publishers on the 'digital bookstore'. Amidst a downturn in the manga digital market in Japan after its peak in 2007, Japanese mobile manga vendors namely NTT Solmare, NEC Biglobe, and the Toppan Printing Company started to find new markets abroad. They created 'Direct-to-digital publishing collectives' to release manga in English licensed by many Japanese publishers on the digital platform in the U.S. (Brienza, 2014).

\section{Discussion}

This study posted two questions (1) Is the concept of innovation limited to technological innovation? and (2) Should the Thai government consider a new possibility to implement its Thailand 4.0 policy that highlights the concept of innovation?

Regarding the first question, the analysis based on Kaya's Schumpeterian trilogy indicates that innovation should not only refer to technology-related creations. Therefore, the definition must not be specified solely on the originality of a creation, its source of raw material, or its method of production but must include the marketability of commodities. The case study of Japanese manga demonstrates that non-technology creations such as manga can be an innovation or cultural innovation to be more specific. Hence, the concept of innovation is not limited to technological innovation.

Regarding the second question, for the new policy to be successful, it is necessary for the Thai government to consider a new possibility to implement the policy. There are two primary ways that the government might pursue to help them reach the vision of Thailand 4.0 policy. First, to execute the policy effectively, it needs to ensure that the public understands the scope of the term 'innovation'. Although, since the launch of Thailand 4.0 policy, the government has accomplished its goal to integrate the concept of innovation in its economic policy, the understanding of the concept among Thai is not completely accurate. 'Innovation' is perceived as the use of new technology as one of national development strategies (Banchanon, 2017). To correct this myth is probably the first step that the government can take to ensure the success of this economic policy. Second, the government may have to be more explicit in the implementation of the policy. Although some may point out that Thailand 4.0 economic policy is an appropriate strategy for the current market, it is also critiqued for its lack of detail in practice (Banchanon, 2017). Moreover, the misconception of the term 'innovation' among the public lessens the possibility to realize the goal of the policy. While the Thailand 4.0 policy may not 
necessarily intend to emphasise only technological innovation, the investment on technological innovation is more prominent in practice. For instance, in the recent five years, The Board of Investment of Thailand (BOI) has reported an increase in the total amount of investment promotion applications in five industry sectors, almost all involve high technology, such as aviation, agriculture and biotechnology, and robotics and automation. The only industry which does not directly relate to non-technological innovation that also applies for the investment promotion project is tourism (Investment Services Center, the Board of Investment Office of the Prime Minister, 2019). However, under the Thailand 4.0 economic model, high valued, creative, cultural commodities and services are one of the industries which the government aims to promote. This means there is still room for the development of non-technological innovation in Thailand to compete in a global market.

The case study of Japanese manga as a cultural innovation suggests that economic success does not rely entirely on the advancement of technology. In case of Thailand, one of the major industries that generates revenue for the country is tourism. Similarly, the success of the industry does not depend on the technology but more on intangible cultural heritage and cultural sites. Another alternative is to bring in the innovation to promote tangible cultural heritage to compete in the global market. Thai manga can help strengthen economic competition in this aspect since it may be developed to encompass the national intangible heritage such as Thai lifestyles, rituals, and ideologies and present them tangibly. Currently, Thai manga may not associate with all types of innovation proposed by Schumpeter especially as a new good and the opening of the new market. This can be done in two steps. First, Thai manga can be introduced as a new good in the publishing market. Taking Japanese manga as a case study, its success in the US market is due to its uniqueness; it is exotic and at the same time universal, so it is relatable to readers in the US. At this stage, Thai manga is highly influenced by Japanese manga. Therefore, it is important for Thai manga artists to find their own voices and create the originality of their work using new source of material. For instance, Thai manga can make use of both Thai intangible culture such as Thai ideologies or lifestyles and popular culture to write the plot or create characters that appeal to local and international readers. Second, after Thai manga develops its own originality, it could lead to the opening of new markets, especially in Southeast Asia. When examining Japanese manga as a cultural innovation, it is revealed that Japanese manga started its global success from the popularity it gained in Asia. This achievement is partly from cultural similarities among Asian countries. Likewise, Thai manga may be able to find its own success in the Southeast Asian market because the 
countries in the region can relate to the culture. The process to create a cultural innovation from this study could be the initial step that the government can develop systematically. In fact, the strategic plan of the Thailand 4.0 policy is to implement the policy via collaboration between public and private sectors. Hence, it is crucial for the government to communicate to the general public the comprehensive dimensions of the key term "innovation". This will help stimulate the creativity necessary from other private sectors for the industry groups related to cultural commodities and lead to Thailand to economic success.

\section{Conclusion}

This paper contributes to a comprehensive concept of innovation. Beyond just an invention for entertainment, manga has evolved to a cross-cultural innovation, the innovation that carries with it the ideologies of the hybridized concepts between the East and the West to communicate with the rest of the world over the language boundary. In this paper, Schumpeter's five types of innovation are used to reconceptualize manga as a cultural innovation. Since in Thailand, most of the time, 'innovation' is tied to technology, discussing manga in this perspective helps bring another facet of innovation into general understanding and practice. This paper argues that the factor that plays a crucial role in leading manga to success in an influential promoter of popular culture like the U.S. is that manga is cultural innovation. It is not simply a cultural innovation created by Japanese people based solely on Japanese culture, but it is a hybridized cultural innovation created by both eastern and western ideologies disguised underneath Japanese appearances.

The implications of this study for Thailand are as follows. In terms of the national policy, if all aspects of 'Innovation' are applied, it will yield many more benefits to the country since it will stimulate creative implementation based on the concept. Thus, the thorough understanding of the concept is crucial for other disciplines since they can take other approaches and create their own innovations. Without such insight, the implementation of the concept can be limited. Furthermore, it should be noted that ideologies and social values could be raw materials for the production of goods. Manga, for example, is the product of cross-cultural innovation and has yielded high profit. On the other hand, Thai values or beliefs can also be reconsidered, reconstructed, and rebranded as a Thai cultural innovation. In a similar way as Japanese manga, Thai manga that contains Thai values or Thai beliefs can go beyond inventions and become a cultural innovation that can contribute to development of Thailand's economy, society, and culture. Creating such innovation is one of the best ways to communicate Thai ideologies to other cultures over the language boundary. 


\section{References}

Anawatkochakorn, S. (1994-1996). Apaimanee Saga (Vol. 1-16). Bangkok, Thailand: Nation Edutainment.

Banchanon, P. (2017, January 6). Wi-khro Thailand 4.0: Wi-sai-that thi yang khat raila-iat [Review of Thailand 4.0: The National Vision with Sketchy Details]. Retrieved from https://www.bbc.com/thai/thailand-38527250

Baumol, W. J. (2015). Joseph Schumpeter: the Long Run, and the Short. Journal of Evolutionary Economics, 25(1), 37-43.

Bouissou, J.-M. (2010). Manga: A Historical Overview. In T. Johnson-Woods (Ed.), Manga: An Anthology of Global and Cultural Perspectives (pp. 17-33). New York, NY: Continuum.

Brienza, C. (2009). Books, not Comics: Publishing Fields, Globalization, and Japanese Manga in the United States. Publishing Research Quarterly, 25(2), 101-117.

Brienza, C. (2014). Did manga conquer America? Implications for the cultural policy of 'Cool Japan'. International Journal of Cultural Policy, 20(4), 383398.

Brophy, P. (2010). Osamu Tezuka's Gekiga: Behind the Mask of Manga. In T. Johnson-Woods (Ed.), Manga: An Anthology of Global and Cultural Perspectives (pp. 128-136). New York, NY: Continuum.

Bryce, M., \& Davis, J. (2010). An Overview of Manga Genres. In T. JohnsonWoods (Ed.), Manga: An Anthology of Global and Cultural Perspectives (pp. 34-61). New York, NY: Continuum.

Chambers, S. N. I. (2012). Anime: From Cult Following to Pop Culture Phenomenon. The Elon Journal of Undergraduate Research in Communications, 3(2), 94-101.

Chan, R. S. K. (2018). Breaking Windows: Malaysian Manga as Dramaturgy of Everyday-Defined Realities. JATI-Journal of Southeast Asian Studies, 23(2), 205-229.

Chen, A. C. (2011). Japan's Illustrated Storytelling: A Thematic Analysis of Globalized Anime and Manga. Keio Communication Review, 33, 85-98.

Chen, A. C. (2012). Cartoon Planet: The Cross-Cultural Acceptance of Japanese Animation. Asian Journal of Communication, 22(1), 44-57.

Cohn, N. (2010). Japanese Visual Language: The Structure of Manga. In T. Johnson-Woods (Ed.), Manga: An Anthology of Global and Cultural Perspectives (pp. 187-203). New York, NY: Continuum.

Couch, N. C. C. (2010). International Singularity in Sequential Art: The Graphic Novel in the United States, Europe, and Japan. In T. Johnson-Woods 
(Ed.), Manga: An Anthology of Global and Cultural Perspectives (pp. 204220). New York, NY: Continuum.

Deloitte Sustainability, British Geological Survey, Bureau de Recherches Géologiques et Minières, Netherlands Organisation for Applied Scientific Research (2017). Study on the Review of the List of Critical Raw Materials. Luxembourg, Luxembourg: Publications Office of the European Union.

Drummond-Mathews, A. (2010). What Boys Will Be: A Study of Shōnen Manga. In T. Johnson-Woods (Ed.), Manga: An Anthology of Global and Cultural Perspectives (pp. 62-76). New York, NY: Continuum.

Goldstein, L., \& Phelan, M. (2009). Are You There God? It's Me, Manga: Manga as an Extension of Young Adult Literature. Young Adult Library Services, 7(4), 32-38.

Ikeda, R. (1972-1973). The Rose of Versailles (Vol. 1-13). Tokyo, Japan: Shueisha.

Imaoka, L. B. (2010). Consuming and Maintaining Difference: American Fans Resisting the Globalization of Japanese Pop Culture. disClosure: A Journal of Social Theory, 19, 73-82.

Investment Services Center, the Board of Investment Office of the Prime Minister. (2019, January 10). BOI recorded investment applications with a value of over 900 billion baht in 2018, 25\% above last year's target [Press release]. $\quad$ Retrieved from https://www.boi.go.th/upload/content/BOI_investment_value_EN_5c373 a42dc3dc.pdf

Ito, K. (2005). A History of Manga in the Context of Japanese Culture and Society. The Journal of Popular Culture, 38(3), 456-475.

Iwabuchi, K. (2002). Recentering Globalization: Popular Culture and Japanese Transnationalism. Durham, NC: Duke University Press.

Johnson-Woods, T. (2010). Introduction. In T. Johnson-Woods (Ed.), Manga: An Anthology of Global and Cultural Perspectives (pp. 1-16). New York, NY: Continuum.

Kaya, P. H. (2015). Joseph A. Schumpeter's Perspective on Innovation. International Journal of Economics, Commerce and Management, 3(8), 25-37.

Martin, J. N., \& Nakayama, T. K. (2010). Intercultural Communication in Contexts. New York, NY: McGraw-Hill Higher Education.

McCraw, T. K. (2007). Prophet of Innovation: Joseph Schumpeter and Creative Destruction. Cambridge, MA: The Belknap Press of Harvard University Press.

Natsume, F. (2004). East Asia and Manga Culture: Examining Manga-Comic Culture in East Asia. In R. G. Abad (Ed.), The Asian Face of Globalisation: 
Reconstructing Identities, Institutions, and Resources: The Papers of the 2001 API Fellows (pp. 95-106). Tokyo: The Nippon Foundation.

Neely, A., Filippini, R., Forza, C., Vinelli, A., \& Hii, J. (2001). A Framework for Analyzing Business Performance, Firm Innovation and Related Contextual Factors: Perceptions of Managers and Policy Makers in Two European Regions. Integrated Manufacturing Systems, 12(2), 114-124.

Okamura, Y., \& Hara, T. (1983-1988). Fist of the North Star (Vol. 1-27). Tokyo, Japan: Shueisha.

Piatti-Farnell, L. (2013). Blood, Biceps and Beautiful Eyes: Cultural Representations of Masculinity in Masami Kurumada's Saint Seiya. Journal of Popular Culture, 46(6), 1133-1155.

Podsatiangool, W. (2017). Why Do Americans Say No to Doraemon? Examining Power Relations Between American and Japanese Popular Culture in Intercultural Communication through the Lens of Semiotics. Journal of English Studies, 12(2), 71-105.

Poitras, G. (2008). What is Manga. Knowledge Quest, 36(3), 49.

Popa, I. L., Preda. G., \& Boldea, M. (2010). A Theoretical Approach of the Concept of Innovation. Proceedings of the Conference on Managerial Challenges of the Contemporary Society, 1, 151-156.

Porter, M. E. (1990). The Competitive Advantage of Nations. Harvard Business Review, 68(2), 73-93.

Prough, J. (2010a). Marketing Japan: Manga as Japan's New Ambassador. ASIANetwork Exchange, 17(2), 54-68.

Prough, J. (2010b). Shōjo Manga in Japan and Abroad. In T. Johnson-Woods (Ed.), Manga: An Anthology of Global and Cultural Perspectives (pp. 93-108). New York, NY: Continuum.

Roland, K. (2006). Japanamerica: How Japanese Pop Culture Has Invaded the U.S. New York, NY: Palgrave Macmillan.

Thai Rath. (2016, May 2). Khai ra-hat pra-thet-thai 4.0: Sang set-tha-kit-mai kao kham kap-dak rai-dai pan-klang [Understand Thailand 4.0: How to create A New Economy and Escape from the Middle Income Trap]. Retrieved from https://www.thairath.co.th/content/613903

Vitoonthong, N., \& Champrasert, B. (1994-present). MEED TEE SIB SAM (Vol. 168). Bangkok, Thailand: Nation Edutainment.

Wutthirong, P. (2014). Kan-chat-kan na-wat-ta-kam: Sap-pha-ya-kon ong-kan-haengkan-rian-ru lae na-wat-ta-kam [Innovation Management: Resource, Learning Organization, and Innovation]. Bangkok, Thailand: Chulalongkorn University Press. 
Jiraporn Phornprapha \& Weerayuth Podsatiangool

Yamato, E. (2012). Accumulating Japanese Popular Culture: Media Consumption Experiences of Malaysian Young Adults. Media Asia, 39(4), 199-208. 